The World Bank's "Employing Workers" index

Findings and critiques - A review of recent evidence

Lee, Sangheon; McCann, Deirdre; Torm, Nina Elisabeth

Published in:

International Labour Review

DOI:

10.1111/j.1564-913X.2008.00043.x

Publication date:

2008

Document version

Publisher's PDF, also known as Version of record

Citation for published version (APA):

Lee, S., McCann, D., \& Torm, N. E. (2008). The World Bank's "Employing Workers" index: Findings and critiques - A review of recent evidence. International Labour Review, 147(4), 416-432.

https://doi.org/10.1111/j.1564-913X.2008.00043.x 


\title{
The World Bank's "Employing Workers" index: Findings and critiques - A review of recent evidence
}

\author{
Sangheon LEE*, Deirdre MCCANN* \\ and Nina TORM**
}

\begin{abstract}
This note provides an update on the ongoing debate over the World Bank's Doing Business project with a particular focus on its "Employing Workers" index, which is intended to measure difficulty of hiring, rigidity of working hours and difficulty of firing. The authors review the findings of studies that have used this index or been influenced by it and of those that inspired its construction. They go on to examine criticisms of this instrument, highlighting both conceptual and empirical problems. Their paper concludes with suggestions for alternative approaches and future research.
\end{abstract}

his his note reviews a growing body of literature on the "Employing Workers" index (EW index) developed by the World Bank as part of its "Doing Business" indicators (DB indicators). This controversial project represents an important attempt to measure "business regulations" and their enforcement across 178 countries, and provide a guide for evaluating regulations that directly impact on economic growth, allowing for cross-country comparisons and identification of good practice (World Bank, 2008). The key product of the DB project is an "ease-of-doing business" index. It is made up of ten sub-indices including the EW index, which measures the cost of labour market regulations. This index is a composite indicator based on measures of three elements: difficulty of hiring; rigidity of working hours; and difficulty of firing. ${ }^{1}$

Since the DB project was launched in 2004, the World Bank's assessment of existing regulations in developing countries has been predominantly negative. Rigid labour market policies are blamed for poor labour market performance, such as low productivity, high unemployment and informal employment, while a more flexible regulatory framework is perceived to be associated with increased growth and employment creation. In a sense, then, this project can be understood as providing an empirical basis for the "augmented Washington Consensus" (Rodrik, 2005), which attributes much of the failure of the "Washington Consensus" in developing countries to the rigidity of their labour markets.

* Senior Researchers, Conditions of Work and Employment Programme, International Labour Office, Switzerland. A research network on Regulating for Decent Work has been established to develop alternative perspectives on labour market regulations. Interested researchers can obtain further details by email from lees@ilo.org or mccann@ilo.org. ** Researcher, Development Economics Research Group (DERG), University of Copenhagen, Denmark. The authors are grateful to two anonymous referees for their helpful comments. We remain, however, responsible for any errors.

Responsibility for opinions expressed in signed articles rests solely with their authors and publication does not constitute an endorsement by the ILO.

${ }^{1}$ For details, see the Doing Business web site: http://www.doingbusiness.org/. 
The pioneering nature of the EW index and its strong policy implications have inspired a growing literature examining the effects of labour market regulations on employment and growth performance, particularly in developing and transition countries. The index has also been subject to strong criticism from trade unions, academics, lawyers and others who question both the orthodox presumption that unregulated labour markets produce better employment outcomes and the methodological foundations of the DB approach.

The remainder of this note is constructed as follows. First, it reviews the findings of studies that use the EW index and Doing Business database for analysis and also those that inspired the index or were influenced by it. The focus is on the impacts of labour regulations on employment, investment and other macroeconomic variables. The paper then looks at the critiques of the index with respect to both conceptual and empirical problems. It concludes with a summary of this literature review and some suggestions for future research.

\section{The Employing Workers index: What have the empirical studies found?2}

\section{Impacts on employment performances}

The study by Botero et al. (2004) that developed the methodology for the EW index concluded that stronger regulation of labour is associated with lower labour force participation and higher unemployment, especially among young workers. Since then, the case for deregulation has drawn support from a number of empirical studies. ${ }^{3}$ For instance, drawing on cross-country evidence, Micco and Pagés (2004) adopted the methodology of Botero et al. (2004) to argue that more stringent job-security regulations slow down gross job flows, especially in sectors that require higher levels of labour flexibility. The UNDP (2004) report, Unleashing Entrepreneurship, which is largely based on the Doing Business report of 2004, finds rigid employment regulations to be related to higher female unemployment. On this basis, the report argues that developing countries should do away with excessively complex labour regulations in favour of simpler rules with higher levels of enforcement. Schiantarelli (2005) suggests a positive effect of less stringent regulation on productivity growth, while Djankov, McLiesh and Ramalho (2006) argue that an improvement in business regulations could lead to GDP increases of up to 2.3 per cent. Czeglédi (2006) observes that countries which regulate more tend to be poorer and grow more slowly, while those regulating less but more coherently have higher levels of development. Examining specific components of regulation, Poschke (2007) finds that firing costs discourage exit of low-productivity firms, congesting the selection process and slowing down growth, and notes that this effect is stronger the

2 Only the papers which used or influenced the DB indicators are reviewed. Other relevant papers on the impacts of labour regulations are mentioned in footnotes.

3 See Djankov (2007) for a recent review of this literature. 
more variable the firm's productivity is. Similarly, Haltiwanger, Scarpetta and Schweiger (2008) argue that stringent hiring and firing regulations distort job flow patterns and thus have an important adverse impact on allocative efficiency, productivity levels and growth. ${ }^{4}$

As regards country-level studies, Heckman and Pagés (2004) draw on a methodology similar to the EW index to conclude that, in the case of Latin America, labour market regulations represent an inequality-increasing mechanism, and that it is generally young, uneducated and rural workers who lose out. These findings are supported by Basu and Maertens (2007), who draw on the EW index to argue that labour regulations constitute one of the main barriers to further economic growth in the Indian economy. Their paper contends that reforms are needed and recommends a labour market system characterized by flexible contracts, a minimal welfare safety-net for unemployed workers, and capacity for swift dispute resolution. ${ }^{5}$ The studies on Brazil by Almeida and Carneiro (2005a and 2005b) find that increased flexibility and easier access to informal labour are generally associated with higher levels of output and value-added per worker. Their argument is that informal employment is an important source of unregulated labour, which may allow firms to operate more efficiently. In the case of Mexico, Mehrez (2005) argues that the large informal sector and the associated externalities and distortions in the economy are attributable to the rigidity of the labour market, measured in terms of the minimum wage, length of the working day and overtime pay.

The relationships between regulation, growth, the informal sector and corruption form the basis of a number of studies. For instance, Loayza, Oviedo and Servén (2004 and 2005a) present evidence that high levels of labour market regulation are associated with lower growth and an expansion of informality. Dreher and Schneider (2006) find that stricter labour regulation is positively associated with corruption and the shadow economy, while better law enforcement shrinks the informal sector. Their paper also notes that in high income countries, corruption and the shadow economy tend to be substitutes, whereas in low income countries they are complements, a finding that may have interesting implications for regulatory policy. ${ }^{6}$ Similarly, a recent study by Dabla-Norris and Inchauste (2008) finds that reducing regulatory constraints increases the

${ }^{4}$ Falk, Huffman and MacLeod (2008) also reported their experimental results that firing threats are crucial for market efficiency, but argued that greater flexibility in contractual instruments (e.g. bonus pay) may undo the negative effects of dismissal barriers. The exact impact of firing threats therefore depends on the institutional environment.

5 Also on India and based on national data sources, a study by Besley and Burgess (2004) concludes that labour regulation has resulted in lower employment, investment and productivity in the formal manufacturing sector, while output in the informal sector has increased. The study also finds little evidence that labour market regulations have promoted the interests of workers, suggesting an association with increases in urban poverty.

${ }^{6}$ Based on the firm-level data from the World Bank, Hallward-Driemeier and Helppie (2007) also find that while higher levels of regulation, discretion and corruption are associated with firms using more flexible labour arrangements, the extent of this actually declines with increased regulation. 
benefits to firms of participating in the formal sector and lowers their incentives to operate informally.

\section{Impacts on investment and enterprises}

Another strand of the regulation literature examines the multiple linkages between labour market institutions, growth, the investment climate and entrepreneurship. For example, Hallward-Driemeier and Stewart (2004) find that a reduction in regulation improves the investment climate, leading to increased productivity, investment and job growth in particular for smaller firms. Also on Latin America, Loayza, Oviedo and Servén (2005b) argue that labour, productmarket and fiscal regulations affect aggregate performance negatively through firm entry and exit, a result supported by Oviedo's study (2006), which also points to unpredictability of regulation as an important source of inefficiency in the factor reallocation process. ${ }^{7}$ A European Commission (2004, chapter 5) study points out that labour market reforms have both direct and indirect productivity impacts, with the former consisting of decreasing costs of doing business and the removal of barriers to penetration of new markets, and the latter operating through higher levels of allocative, productive and dynamic efficiency. Similarly, Desai, Gompers and Lerner (2005) find that increased levels of labour regulation are associated with reduced entry and exit, smaller average firm size, and greater distortion in firm-size distribution.

Also on firm characteristics, Jacobs and Coolidge (2006) suggest that small- and medium-sized enterprises (SMEs) operating on the fringe of the formal market are particularly sensitive to a high-cost regulatory environment and are therefore likely to be key beneficiaries of regulatory reforms. Van Stel, Storey and Thurik (2006) argue that labour market regulations lower entrepreneurship rates, ${ }^{8}$ and Klapper et al. (2007) suggest significant positive linkages between the quality of regulatory environments and levels of entrepreneurship. Pierre and Scarpetta (2004) suggest that overly ambitious labour regulations raise labour costs and curb incentives for firms to hire more workers and adopt new technologies, which in turn reduces the reallocation of labour to productive jobs in the formal economy. However, their study also points out that these effects differ according to firm type and size, and that employers often make use of on-the-job training and temporary employment measures to compensate for stringent employment protection legislation. These findings are echoed in their later paper (Pierre and Scarpetta, 2007), which notes that labour market reforms may not succeed unless accompanied by improvements in social protection mechanisms that cushion adjustment costs for workers. Ardagna and Lusardi

\footnotetext{
7 An earlier study by Oviedo (2004) compared the experiences of eastern Europe, the OECD and Latin America and concluded that the reason Latin America benefited less from regulatory change than the transition countries is that the pace of reform was not sufficient to generate significant differences in firm dynamics.

8 It should be noted that this finding is based on the assumption that country differences in regulations are stable across different firm sizes, which puts into question the reliability of the results.
} 
(2008) argue that regulation is detrimental to entrepreneurship, especially through its impact on social networks, business skills, and working status. However, their study also finds that regulation strengthens the impact of attitudes toward risk.

\section{Impacts on macroeconomic performances}

Another group of studies focuses on the relationship between regulation, trade and foreign direct investment (FDI). Javorcik and Spatareanu (2004) suggest that as the labour market in a host country becomes more flexible, FDI may increase by as much as 18 per cent. This effect is suggested to be particularly strong in transition economies and more significant for investments in the service sector than in manufacturing. Similarly, Busse and Groizard (2006) find evidence that excessive regulation restricts growth by lowering levels of FDI. With regard to trade, Bolaky and Freund (2005) find that in heavily regulated countries the effect of trade on long-run growth is non-existent at best and negative at worst and associated with a lower standard of living. Loayza and Raddatz (2006) find that improvements in labour market flexibility lessen the negativeoutput impact of terms-of-trade shocks, while in rigid labour markets domestic financial robustness may help reduce the effect of external shocks. Borrmann, Busse and Neuhaus (2006) find that countries with excessive regulations and low-quality institutions have been unable to take full advantage of trade liberalization and conclude that reforming regulatory frameworks is essential to achieving positive welfare gains from trade and FDI inflows. Supporting this finding, Helpman and Itskhoki (2007) conclude that countries with less "labour market friction" gain more from trade, but they also note that differences in unemployment rates associated with trade do not necessarily reflect differences in rigidity levels. Cuñat and Melitz (2007) present evidence that countries with more flexible labour markets have a comparative advantage in sectors where the ability to adjust is more important, e.g. sectors subject to high-variance shocks. They also suggest that a rigid economy can be improved by liberalizing trade and importing flexibility from a more flexible trading partner, rather than labour market deregulation.

\section{The critiques: Problems with the premises of the EW index}

As the previous section indicates, the EW index has had a significant influence on labour research. It has also been influential in labour market policy debates, particularly in developing and transition countries. However, critiques of the index have also increased in number and intensity. In the early work, critics did not subject the EW index to empirical testing, tending instead to concentrate on its foundations, which had been broadly accepted in the empirical studies. Critics have been particularly concerned with the use of the EW index - and in particular the country rankings - to guide legal reform, as a benchmark against which to measure progress and a basis for providing financial assistance to developing countries. The focus of the critiques, then, was conceptual and methodo- 
logical rather than the econometrical "robustness" of the indices. In recent years, however, the critiques of the DB project have broadened to encompass empirical tests that are based on new data and analysis. This section reviews both of these strands of the research.

\section{Conceptual and measurement problems}

The conceptual and methodological foundations of the EW index and broader DB project are challenged in the literature as problematic or unreliable. ${ }^{9}$ The conceptual limitations of the project can be argued to stem from its underlying understanding of labour laws, which are grouped together with the other legal measures covered by the index as a form of "business regulation". This conceptualization of labour standards differs from conventional accounts of their purpose in policy, legal and other discourses, which tend to centre on the social objectives of such standards, e.g. ensuring justice, protecting workers' well-being and security, or improving the quality of life of workers and their families. ${ }^{10}$

In line with this classification of labour laws as an element of "the business environment", the DB indicators are intended neither to recognize the social objectives of labour regulations, nor to assess the level of protection offered by the domestic standards they cover. As a result, a key concern that has been raised by both trade unions and researchers is that, aside from the ILO's core labour standards, ${ }^{11}$ the EW index disregards many of the entitlements contained in ILO standards. ${ }^{12}$ For example, Lee and McCann (2008) have carried out an analysis with respect to the international standards on working time, finding the sub-index on "rigidity of hours" to be substantially in conflict with them. Also, the 2008 DB report singles out Georgia as a model of labour market regulation (World Bank, 2008, p. 19), although its labour code has been heavily criticized by the ILO for granting employers an unlimited right to dismiss workers without cause and imposing severe restrictions on trade union action and workers' collective bargaining rights.

In terms of the overall country rankings, moreover, the EW index generates some striking results that are, in some cases, out of line with the economic outcomes it purports to measure. Because of their deregulated labour markets, countries like Afghanistan, Haiti and Papua New Guinea, for example, earn higher marks on the index than do prosperous economies with low levels of unemployment and high productivity, such as Finland, the Netherlands and Sweden, contradicting the World Bank's claim that more flexible policies are a

${ }^{9}$ See, for instance, Kitching (2006), Arruñada (2007 and 2008), Berg and Cazes (2007) and Lee and McCann (2008) for recent critiques, and Djankov's (2008) response.

10 On the objectives underlying the international labour standards, for example, see Langille (2005) and Murray (2001).

11 These standards are enunciated in the ILO's 1998 Declaration on Fundamental Principles and Rights at Work. They cover standards on freedom of association and collective bargaining, forced and child labour, and workplace discrimination.

12 The 2008 DB report claims that methodological improvements have aligned the EW index with the ILO's Conventions (for more detail, see Doing Business, 2008, p. 68). 
recipe for high-quality job creation. In this context, Global Unions has suggested that by discouraging countries from maintaining anything above the bare minimum level of labour market regulation, the DB project undermines the development goals promoted by international organizations, including the World Bank itself (ITUC/Global Unions, 2007, p. 2).

Detailed analyses of individual indicators shed light on such outcomes and raise questions about a number of the sub-indices and legislated standards that are absent from the evaluation. Examination of the "rigidity of hours" subindex, for example, shows it to be broadly out of step with trends in domestic regulation and also to reward substantially deregulated working time regimes (Lee and McCann, 2008). McLeod (2007) argues that the "rigidity of employment" component of the EW index provides no additional information: its only effect, he suggests, is to introduce a bias towards the interests of employers by adding weight to the "hiring", "firing" and "rigidity of hours" sub-indices. And Berg and Cazes (2007) point to the absence from the Index of tripartite negotiation and collective bargaining measures, despite their role in encouraging dynamic and responsive labour markets. ${ }^{13}$

The literature also questions the models of "the business" and "the worker" that are applied to evaluate labour legislation for the purposes of the DB index. ${ }^{14}$ Assumptions about "the business" include, for example, that it is a limited liability company; operates in the manufacturing sector; and has 201 employees. A number of studies have noted that this model of the firm does not represent the bulk of the private sector in many developing countries, most notably because it misses the micro-enterprises that are characteristic of the informal sector. ${ }^{15}$ In the case of sub-Saharan Africa, for example, Kitching (2006) has argued that since the DB project assumes a model of the enterprise atypical of the vast majority of micro- and small enterprises, it is unable to offer meaningful information on any growth constraints that may affect these businesses. The image of "the worker" embedded in the index is also open to criticism as reflecting the "standard" model of labour market participation in that he or she is assumed to be 42 years old, engaged on a full-time basis and to have been employed by the same company for 20 years. This model of engagement in paid labour, however, is alien to many workers - and women in particular across the industrialized countries, and it captures only a minority of workers in many developing countries. ${ }^{16}$

Along the same lines, Siems (2007) argues that by comparing countries in which the context of particular rules is completely different, the DB approach

13 See also du Marais (2006), Association Henri Capitant des amis de la culture juridique Française (2006) and McLeod (2007).

14 On the methodology of the EW index, see http://www.doingbusiness.org/Methodology Surveys/EmployingWorkers.aspx (accessed 5 September 2008).

15 See Palmer, Wedgwood and Hayman (2007), Berg and Cazes (2007) and UNIDO/GTZ (2008).

16 On the regulation of precarious forms of work in industrialized economies, see Fudge and Owens (2006). 
does not allow for an assessment of individual countries' legal systems, thereby undermining the overall ranking system. Bath's (2007) study of the application of the index to China and Australia contends that the restricted scope of the EW index means that the overall DB index does not provide an accurate picture of "ease of doing business", thereby restricting its usefulness both for analyses of individual countries and for cross-country comparisons. Also, questioning whether the EW index accurately captures the employment climate best suited to business, Høyland, Moene and Willumsen (2008) argue that countries may actually find it easier to shift their rankings in the index than to change their underlying business environment. This supports the suggestion of Ménard and du Marais (2006) that the DB ranking system is superficial and measures the ability of countries to "fix the rules of the game". Overall, the current state of knowledge on the workings of labour legislation does not validate the belief that labour law reform towards deregulation will enable countries to improve their economic performance (Deakin, Lele and Siems, 2007). These conceptual and methodological deficiencies of the EW index stand in contrast with the increasing references being made to it within global policy circles, raising suspicion in some quarters that the main motivation behind the EW index is international trade goals - e.g. global competition for labour deregulation - rather than questions of national development (Villalba, 2006).

With regard to the measurement of legislative prescriptions, a number of studies have made the point that the EW index is based on de jure regulatory policies, and that since these do not necessarily reflect de facto practices, the ability of the EW index to assess the economic impact of specific legal instruments is limited. ${ }^{17}$ Chor and Freeman (2005), for example, find no correlation between the EW index and the corresponding measure in their Global Labour Survey, namely, the index on "Employment Regulations and Working Conditions", which is based on the de facto application of regulations. They conclude that the measurement of de jure regulations does not provide a reliable indication of workplace practice. Similarly, Lee and McCann (2008) construct an index of effective regulation intended to capture both the de jure and the de facto perspectives: they find substantial cross-country variations in the relation between working time regulation, income and the observance of legal measures. Eifert's (2007) study, which finds that de jure regulatory reform over the period 2003-06 did not significantly boost aggregate investment or employment (at least in the short run), also lends support to the view that one should be cautious about using the existing institutional indicators to make causal claims about the impact of regulatory reforms (see also Benjamin and Theron, 2007, on South Africa).

17 See among others Jacobs and Coolidge (2006), Chor and Freeman (2005), du Marais (2006) and Lee and McCann (2008). In the case of Viet Nam, this limitation is raised by the Viet Nam Provincial Competitiveness Index (VPCI), which attributes the difference between the outcomes of the DB index and the VPCI to the fact that the DB ranking is based on de jure policies whereas the VPCI focuses on whether the regulations are faithfully implemented (see USAID/ VCCI, 2007). 


\section{Benefits of labour regulations}

As alluded to in the previous section, a further critique that has been directed at the EW index centres not on its inability to capture the social goals of labour market regulation, but instead on its failure to recognize and measure the ways in which labour laws can generate positive economic outcomes. In this regard, the index is criticized for assuming that deregulated markets foster economic growth and for embodying indicators that measure the level of deregulation rather than accurately capturing the relationship between legal measures and economic outcomes.

The labour law literature offers accounts of how labour regulation can advance economic goals, outlining a role for labour standards in generating positive economic outcomes, particularly by enhancing dynamic efficiencies. Recent work has provided theoretical justifications for regulating work in which economic efficiency considerations complement the traditionally dominant social objectives (see, in particular, Deakin and Wilkinson, 1991 and 2000). This work offers a model for understanding how labour standards can generate longterm economic gains by protecting the interests of firms that adopt a highproductivity route to competitiveness, i.e. by preventing other firms from competing against them on the basis of poor working conditions. Regulatory measures thereby "channel" competition away from the unacceptable treatment of workers into other sources of competitive advantage, such as technological, organizational or managerial innovation. Similarly, Kitching (2006) argues that it is important to consider both the direct and the indirect impacts of regulations, noting that they may also enable and motivate business owners, rather than simply constrain them.

Moreover, a growing body of empirical evidence suggests that relatively substantial regulation does not necessarily lead to weaker labour market outcomes. Bertola (2005 and forthcoming) - one of the first to question the premises of the EW index - casts doubt on the view that all labour market regulations have adverse employment and welfare effects. Similarly, Arpaia and Mourre (2005) argue that the costs and benefits of regulation change over time and that regulation per se cannot be considered a hindrance to the flexible working of the labour market. The importance of the specific country-context is highlighted in several studies, including Oviedo's (2004) comparative assessment of eastern European, OECD and Latin America countries. The UNIDO/GTZ (2008) report on sub-Saharan Africa also finds little evidence that "inappropriate" labour regulations are a significant constraint on growth, pointing to the shortage of skilled labour as a much more serious limitation. Moreover, as regards the Middle East and North Africa, a recent World Bank (2007) report finds that for this region's countries as a whole, regulatory frameworks do not impose a constraint on business. Nor does the study by Jha and Golder (2008) on India find any evidence that protective labour market interventions are a hindrance to development. The authors also note that in order to understand output or employment performance a whole range of variables must be considered in addition to labour laws. 
In terms of cross-country investigations, the analysis by Howell et al. (2006) finds no evidence that protective labour market institutions are associated with adverse growth and development outcomes. Their study notes that unemployment benefit generosity might be an exception, although the direction of causality is questioned. Similarly, Blanchet (2006) finds no obvious relation between increased employment flexibility and higher levels of human development and other macroeconomic variables. His study argues that using composite indicators to rank countries may be misleading and concludes that the DB index explains very little in terms of the variations of macroeconomic variables across countries. Moreover, a couple of recent studies - by Commander, Svejnar and Tinn (2008) and Commander and Svejnar (2008) use the World Bank's Enterprise Surveys dataset and the DB database to show that improvements in the EW index (and in the overall DB index) do not seem to be related to GDP growth or higher levels of employment. The authors attribute these results both to the manner in which the DB indicators are measured and to the complexity of the underlying relationships. They conclude that "country-fixed effects" may be more important in explaining firm performance than differences in institutional environments.

In more general terms, as Arruñada (2007) has pointed out, in spite of the lack of attention paid by the DB index to the potential benefits of protective labour market regulation, there is growing evidence that regulation may entail both economic and social benefits. Loayza, Oviedo and Servén (2005a), for instance, point to the potentially positive impact of regulation on social objectives such as workers' safety and welfare; and a study by McCann and Lee (2007) suggests ways in which working time regulation can be designed to contribute to economic efficiency. Kiliçaslan (2005) finds that regulations on conditions of employment, labour administration and training may bring about increased productivity, while wage flexibility appears to be detrimental to growth in manufacturing. On the application of labour law in micro- and small- enterprises, Fenwick et al. (2007) suggest that regulation can play an important role in promoting job quality, stabilization and growth. Similarly, a recent ILO study on Ghana suggests that regulations can benefit employers by facilitating productivity gains, concluding that repealing labour legislation will not necessarily ensure business sustainability (GEA/ILO, 2008).

Moreover, in relation to firing costs, Bird and Knopf (forthcoming) find that the costs imposed upon employers by "wrongful discharge" laws (in the form of increased labour expenses and lower profitability) appeared only during the first year after their adoption and may not be as high as implied by the EW index. Almeida and Aterido (2008) also find a positive correlation between the enforcement of labour regulations and investment in job training, especially in the manufacturing sector and among low-tech industries. Their study notes that this effect works mostly through the rigidity and cost of hiring regulations rather than legal provisions on the firing of workers.

Finally, a related point, often raised by trade unions, is that by focusing solely on the costs of regulation, the EW index does not consider the costs of 
labour market deregulation, notably in regard to social security (Bakvis, 2006). Also on this issue, and in response to the UNDP (2004) report on Unleashing entrepreneurship, Trebilcock (2006) notes that the study fails to address the consequences of reduced social protection associated with deregulatory reform, and does not question the relationships between specific labour law measures and the incidence of poverty.

\section{Concluding remarks: The way forward - getting the basics right?}

The observed conceptual shortcomings and methodological limitations of the EW index suggest that using it to derive conclusions about overall labour market rigidities may not simply lead to dubious outcomes but may even be highly misleading. In addition, the rather simplistic claim that regulation is an obstacle to economic growth and development, which is based on the assumption that regulation entails only costs, has been called into question by evidence pointing to the potential benefits of regulation.

Based on the empirical evidence reviewed in this note, the effects of labour market institutions appear to be more complicated than implied by the DB approach. A more realistic approach might therefore be to allow for country variations in coverage and implementation of labour laws, considering both direct and indirect impacts of these regulations, and recognizing that the balance of their costs and benefits may change over time. The complexity of the regulation-employment relationship arises from the fact that labour institutions are embedded in social norms and systems of production and often form part of complementary laws and policies. For instance, as is noted by McCann, many of the labour rights extended to workers in the Asian region were enacted as part of democratization processes (see McCann, 2008).

Our literature review indicates that the current understanding of labour regulation and its impacts on economic and labour market performances may not be sufficient to develop a policy guideline of universal applicability. The problem appears to begin with the basics. The assumption underlying the EW index is that labour regulation is the outcome of the rent-seeking activities of "insiders". In this understanding, as Lindbeck and Snower (2001) suggest, the focus tends to be on "unequal power" among workers, with the deregulatory policy measures intended to reduce the influence of "insiders". This approach has the effect of shifting away from "labour regulation as a way of addressing the relationship between workers and employers" and concentrating on a rather secondary aspect of labour regulation, such as potentially different interests between workers. It also has the effect of supporting the neo-classical view that labour regulation introduces distortions into otherwise efficient markets.

This unbalanced understanding, as discussed above, has led institutional indicators such as the EW index to be designed without consideration of the potential benefits of regulation. As Agell (2004) has pointed out, "[t]he intellectual support ... for far-reaching labour market deregulation ... can be traced to 
investigations that assume ... a perfectly competitive labour market. Though such an approach might be useful in mapping out the costs of labour market institutions, it has nothing to say about potential benefits" (p. 260). As a result, in economic studies of labour regulation, the analysis "has been mostly conducted within a framework that does not justify its existence" (Pissarides, 2001). However, it is equally difficult to say that the benefits of labour regulation are well understood and effectively measured by its supporters. As noted earlier, there have been some attempts to demonstrate these positive aspects, but the conceptual framework remains relatively weak and does not extend beyond the "market failure" argument. Relevant measurement work is also lacking. A central limitation of these studies, for example, is that they are restricted to outlining the economic impacts of legal measures, rather than offering a detailed analysis of the conditions from which these emerge. ${ }^{18}$

Significantly, the realization that the relationship between regulation, employment and growth is more complex than assumed by existing institutional indicators appears to be gaining ground, even among proponents of deregulation. For instance, Mehrez (2005), Oviedo (2006) and Dabla-Norris and Inchauste (2008) all note the importance of the quality of regulation in curbing its potentially negative effects and the potential for improved enforcement of legal standards to reduce the "shadow economy" and address corruption. As recent studies imply, the interactions between different institutions and policies may be critically important in determining the nature and scale of their respective impacts on labour market outcomes (e.g. between minimum wages and taxation, or employment protection laws and training), but the current understanding of such institutional interaction is very limited and no firm conclusion can be drawn as yet (see Bertola, forthcoming, for a review; Bassanini and Duval, 2006).

All in all, then, there is a growing recognition that regulation must be evaluated in a comprehensive context that captures how specific legal rights and obligations are articulated within the broader legal systems and policy contexts in which they are embodied. This attentiveness to the policy measures needed to accompany and support regulatory reform allows a more sophisticated understanding of the package of policy measures that are required for legal measures to advance economic outcomes. In this regard, individual country case-studies or comparative studies that take into account structural and political frameworks may provide a more accurate assessment than cross-country examinations. In particular, this approach would allow specific development contexts to be considered in a more explicit manner. As indicated above, for example, in the many African countries where only a small share of the workforce is employed in the formal sector, "formalization" rather than "deregulation" of the labour market may constitute a key policy priority.

18 An exception is Bosch and Lehndorff's (2001) review of the employment effects of collective working-time reductions in Europe during the 1980s and 1990s, which offers a model of a more sophisticated analysis. Their study considers not only the economic impacts of regulatory measures but also the conditions in which beneficial impacts are more likely to emerge. 
The foregoing review suggests that the developing world would probably gain more from the debate on regulation if it were to shift from a focus on whether to deregulate towards a consideration of how individual countries can best promote labour laws and policies that respond to their current development challenges. Within the legal literature, for example, promising avenues of recent scholarship question how legal techniques can be redesigned or enhanced to realize their goals more readily. This work draws on advances in regulatory theory to explore how labour rights can be advanced in more effective ways than by conventional "command and control" mechanisms alone, through new or overlooked regulatory techniques such as financial incentives, government contracts, codes of practice, etc. (see, in particular, Fenwick et al., 2007). ${ }^{19}$ This work also offers a promising avenue towards focusing not so much on a retreat from substantive legal standards, as on the design of procedural and implementation mechanisms to ensure that legal rights are realized in practice, and on identification of the most effective combinations of regulatory techniques to advance both social and economic objectives.

\section{References}

Agell, Jonas. 2004. "Efficiency and equality in the labour market", in CESifo Economic Studies, Vol. 50, No. 2, pp. 255-278.

Almeida, Rita K.; Aterido, Reyes. 2008. Labor market regulations and the investment in job training in developing countries. Washington, DC, World Bank.

-; Carneiro, Pedro. 2005a. Does labor flexibility affect firm performance? Evidence from Brazil. Washington, DC, World Bank.

-; - .2005b. Enforcement of regulation, informal labor and firm performance. IZA Discussion Paper No. 1759. Bonn, Institute for the Study of Labor (IZA).

Ardagna, Silvia; Lusardi, Annamaria. 2008. Explaining international differences in entrepreneurship: The role of individual characteristics and regulatory constraints. NBER Working Paper No. 14012. Cambridge, MA, National Bureau of Economic Research.

Arpaia, Alfonso; Mourre, Gilles. 2005. Labour market institutions and labour market performance: A survey of the literature. Directorate-General for Economic and Financial Affairs Economic Papers No. 238. Brussels, European Commission.

Arruñada, Benito. 2008. How Doing Business jeopardizes institutional reform. Economics and Business Department Working Paper No. 1088. Barcelona, Pompeu Fabra University.

-. 2007. "Pitfalls to avoid when measuring institutions: Is 'Doing Business' damaging business?", in Journal of Comparative Economics, Vol. 35, No. 4, pp. 729-747.

Association Henri Capitant des Amis de la Culture Juridique Française. 2006. Les droits de tradition civiliste en question: À propos des Rapports Doing Business de la Banque Mondiale. Paris, Société de Législation Comparée.

Bakvis, Peter. 2006. How the World Bank and IMF use the Doing Business Report to promote labour market deregulation in developing countries. Washington, DC, ICFTU/Global Unions.

Bassanini, Andrea; Duval, Romain. 2006. Employment patterns in OECD countries: Reassessing the role of policies and institutions. OECD Social, Employment and Migration Working Papers No. 35. Paris, OECD.

19 This understanding of legal regulation is also central to the network on Regulating for Decent Work referred to above. 
Basu, Kaushik; Maertens, Annemie. 2007. The pattern and causes of economic growth in India. Center for Analytical Economics (CAE) Working Paper 07-08. Ithaca, NY, Cornell University.

Bath, Vivienne. 2007. The World Bank Doing Business Reports - Regulation and change in China and Australia. Sydney Law School Research Paper No. 07/79. Sydney, University of Sydney.

Benjamin, Paul; Theron, Jan. 2007. Costing, comparing and competing: Developing an approach to the benchmarking of labour market regulation. Development Policy Research Unit Working Paper No. 07/131. Rondebosch, University of Cape Town.

Berg, Janine; Cazes, Sandrine. 2007. The Doing Business Indicators: Measurement issues and political implications. Economic and Labour Market Paper No. 2007/6. Employment Analysis and Research Unit, Economic and Labour Market Analysis Department. Geneva, ILO.

-; Kucera, David (eds). 2008. In defence of labour market institutions: Cultivating justice in the developing world. Houndmills, Palgrave Macmillan.

Bertola, Giuseppe. Forthcoming. Labour market regulation: Motives, measures, effects. ILO Conditions of Work and Employment Research Series. Geneva.

-. 2005. "Distribution, efficiency, and labor market regulation: In theory, in OECD countries, and in Latin America", in Jorge E. Restrepo and Andrea Tokman R. (eds): Labor markets and institutions. Santiago, Central Bank of Chile, pp. 17-60.

Besley, Timothy; Burgess, Robin. 2004. "Can labor regulation hinder economic performance? Evidence from India”, in Quarterly Journal of Economics, Vol. 119, No. 1 (Feb.), pp. 91-134.

Bird, Robert C.; Knopf, John D. Forthcoming. "Do wrongful discharge laws impair firm performance?", in Journal of Law and Economics (May 2009).

Blanchet, Didier. 2006. Exploratory analysis of the indicators proposed by the Doing Business Reports 2005 and 2006 of the World Bank. Working Paper AED-EAL-2006-3. Research Program "Economic Attractiveness of the Law", Nanterre, Université Paris 10.

Bolaky, Bineswaree; Freund, Caroline. 2005. Trade, regulations, and growth. Paper presented at the Trade and Growth Conference, Research Department, hosted by the IMF in Washington, DC, on 9 January 2006.

Borrmann, Axel; Busse, Matthias; Neuhaus, Silke. 2006. Institutional quality and the gains from trade. HWWA Discussion Paper No. 341. Hamburg, Hamburg Institute of International Economics (HWWA).

Bosch, Gerhard; Lehndorff, Steffen. 2001. "Working-time reduction and employment: Experiences in Europe and economic policy recommendations", in Cambridge Journal of Economics, Vol. 25, No. 2 (Mar.), pp. 209-243.

Botero, Juan C.; Djankov, Simeon; La Porta, Rafael; Lopez-de-Silanes, Florencio; Shleifer, Andrei. 2004. "The regulation of labor", in Quarterly Journal of Economics, Vol. 119, No. 4 (Nov.), pp. 1339-1382.

Busse, Matthias; Groizard, José Luis. 2006. FDI, regulations and growth. HWWA Discussion Paper No. 342. Hamburg, Hamburg Institute of International Economics (HWWA).

Chor, Davin; Freeman, Richard B. 2005. The 2004 Global Labor Survey: Workplace institutions and practices around the world. NBER Working Paper No. 11598. Cambridge, MA, National Bureau for Economic Research.

Commander, Simon; Svejnar, Jan. 2008. Do institutions, ownership, exporting and competition explain firm performance? Evidence from 26 transition countries. IZA Discussion Paper No. 2637. Bonn, Institute for the Study of Labor (IZA).

-; -; Tinn, Katrin. 2008. Explaining the performance of firms and countries: What role does the business environment play? Discussion Paper No. 1(E)-2008. St. Petersburg, St. Petersburg State University, Graduate School of Management, Institute of Management.

Cuñat, Alejandro; Melitz, Marc J. 2007. Volatility, labour market flexibility, and the pattern of comparative advantage. CEPR Discussion Paper No. 6297. London, Centre for Economic Policy Research. 
Czeglédi, Pál. 2006. "Economic growth and institutional coherence", in New Perspectives on Political Economy, Vol. 2, No. 2, pp. 1-25.

Dabla-Norris, Era; Inchauste, Gabriela. 2008. "Informality and regulations: What drives the growth of firms?", in IMF Staff Papers, Vol. 55, No. 1, pp. 50-82.

Deakin, Simon; Lele, Priya; Siems, Mathias. 2007. "The evolution of labour law: Calibrating and comparing regulatory regimes", in International Labour Review, Vol. 146, No. 3-4, pp. 133-162.

-; Wilkinson, Frank. 2000. "Labour law and economic theory: A reappraisal", in Hugh Collins, Paul Davies and Roger Rideout (eds): Legal regulation of the employment relation. London, Kluwer Law International, pp. 29-62.

-; - . 1991. "Labour law, social security and economic inequality", in Cambridge Journal of Economics, Vol. 15, No. 2 (June), pp. 125-148.

Desai, Mihir; Gompers, Paul; Lerner, Josh. 2005. Institutions, capital constraints and entrepreneurial firm dynamics: Evidence from Europe. Harvard NOM Research Paper No. 03-59. Cambridge, MA, Harvard Business School, Negotiation, Organizations and Markets Unit.

Djankov, Simeon. 2008. A response to Is Doing Business Damaging Business. Washington, DC, World Bank.

-. 2007. Measuring the ease of enterprise. Washington, DC, World Bank.

-; McLiesh, Caralee; Ramalho, Rita Maria. 2006. Regulation and growth. Washington, DC, World Bank.

Dreher, Axel; Schneider, Friedrich. 2006. Corruption and the shadow economy: An empirical analysis. IZA Discussion Paper No. 1936. Bonn, Institute for the Study of Labor (IZA).

Eifert, Benjamin P. 2007. The economic response to regulatory reform, 2003-06. Berkeley, CA, Department of Economics, University of California.

European Commission. 2004. The EU Economy: 2004 Review. ECFIN (2004) REP 50455EN. Brussels, Directorate General for Economic and Financial Affairs (ECFIN).

Falk, Armin; Huffman, David; MacLeod, W. Bentley. 2008. Institutions and contract enforcement. NBER Working Paper No. 13961. Cambridge, MA, National Bureau of Economic Research.

Fenwick, Colin; Howe, John; Marshall, Shelley; Landau, Ingrid. 2007. Labour and LabourRelated Laws in Micro and Small Enterprises: Innovative Regulatory Approaches. SEED Working Paper No. 81. Small Enterprise Programme, Job Creation and Enterprise Development Department. Geneva, ILO.

Fudge, Judy; Owens, Rosemary. 2006. Precarious work, women and the new economy: The challenge to legal norms. Oxford, Hart Publishing.

GEA/ILO. 2008. Survey on the Employing Workers index of the World Bank Doing Business reports. Prepared for the Workshop on World Bank Employing Workers Index for Ghana, held in Accra on 24 March 2008.

Hallward-Driemeier, Mary; Helppie, Brooke. 2007. Why don't firms take advantage of more flexible labor options? Regulation, enforcement and corruption. IPC Working Paper Series No. 38. Ann Arbor, MI, International Policy Center, University of Michigan.

-; Stewart, David. 2004. How do investment climate conditions vary across countries, regions and types of firms? Background paper prepared for the World Development Report 2005: A better investment climate for everyone. Washington, DC, World Bank.

Haltiwanger, J.; Scarpetta, S.; Schweiger, H. 2008. Assessing job flows across countries: The role of industry, firm size and regulations. NBER Working Paper No. 13920. Cambridge, MA, National Bureau of Economic Research.

Heckman, James J.; Pagés, Carmen (eds). 2004. Law and employment: Lessons from Latin America and the Caribbean. National Bureau of Economic Research Conference Report. Chicago, IL, University of Chicago Press.

Helpman, Elhanan; Itskhoki, Oleg. 2007. Labor market rigidities, trade and unemployment. NBER Working Paper No. 13365. Cambridge, MA, National Bureau of Economic Research. 
Howell, David R.; Baker, Dean; Glyn, Andrew; Schmitt, John. 2006. "Are protective labour market institutions really at the root of unemployment? A critical perspective on the statistical evidence", in Capitalism and Society, Vol. 2, No. 1, pp. 1-73.

Høyland, Bjørn; Moene, Kalle; Willumsen, Fredrik. 2008. Be careful when Doing Business. Report commissioned by the Norwegian Ministry of Foreign Affairs. Oslo, ESOP (Centre of Equality, Social Organization and Performance, University of Oslo).

ITUC/Global Unions. 2007. The IFIs' use of Doing Business to eliminate workers' protection: Analysis of Doing Business 2008 and new country evidence. Washington, DC.

Jacobs, Scott; Coolidge, Jacqueline. 2006. Reducing administrative barriers to investment: Lessons learned. FIAS Occasional Paper No. 17. Foreign Investment Advisory Services. Washington, DC, World Bank.

Javorcik, Beata Smarzynska; Spatareanu, Mariana. 2004. Do foreign investors care about labor market regulations? Policy Research Working Paper No. 3275. Washington, DC, World Bank.

Jha, Praveen; Golder, Sakti. 2008. Labour market regulation and economic performance: $A$ critical review of arguments and some plausible lessons for India. Economic and Labour Market Papers No. 2008/1. Geneva, ILO.

Kiliçaslan, Yilmaz. 2005. Industrial structure and labour markets: A study on productivity growth. Thesis submitted to the Graduate School of Social Sciences of Middle East Technical University, Ankara.

Kitching, John. 2006. A burden on business? Reviewing the evidence base on regulation and small-business performance. London, Kingston University Research Repository.

Klapper, Leora; Amit, Rafael; Guillen, Mauro F.; Quesada, Juan Manuel. 2007. Entrepreneurship and firm formation across countries. Policy Research Working Paper No. 4313. Washington, DC, World Bank.

Langille, Brian. 2005. What is international labour law for? Geneva, International Institute for Labour Studies.

Lee, Sangheon; McCann, Deirdre. 2008. "Measuring labour market institutions: Conceptual and methodological questions on "working hours rigidity", in Janine Berg and David Kucera (eds): In defence of labour market institutions: Cultivating justice in the developing world. Houndmills, Palgrave Macmillan, pp. 32-63.

Lindbeck, Assar; Snower, Dennis J. 2001. "Insiders versus outsiders", in Journal of Economic Perspectives, Vol. 15, No. 1, pp. 165-188.

Loayza, Norman V.; Oviedo, Ana María; Servén, Luis. 2005a. The impact of regulation on growth and informality: Cross-country evidence. Policy Research Working Paper No. 3623. Washington, DC, World Bank.

-; -; -. 2005b. Regulation and microeconomic dynamics: A comparative assessment for Latin America. Washington, DC, World Bank.

-; -; -. 2004. Regulation and macroeconomic performance. Policy Research Working Paper No. 3469. Washington, DC, World Bank.

-; Raddatz, Claudio. 2006. The structural determinants of external vulnerability. Policy Research Working Paper No. 4089. Washington, DC, World Bank.

Marais, Bertrand du. 2006. Methodological limits of "Doing Business" reports. Working Paper AED-2006-1 (Version 4). Research Program "Economic Attractiveness of the Law", Nanterre, Université Paris 10.

McCann, Deirdre. 2008. "The regulation of working conditions in Asia and the Pacific: Flexibility, fragmentation and workers' rights", in Sangheon Lee and François Eyraud (eds): Globalization, flexibilization and working conditions in Asia and the Pacific. Geneva, ILO, pp. 81-112.

-; Lee, Sangheon. 2007. How to defend labour standards: A case study on working hours limits. Draft paper for the ILO Workshop on the Economic Dynamics of International Labour Standards, held at the International Labour Office, Geneva, 21-22 June 2007.

McLeod, Ross H. 2007. Doing Business in Indonesia: Legal and bureaucratic constraints. Working Paper AED-EAL-2007-3. Research Program "Economic Attractiveness of the Law", Nanterre, Université Paris 10. 
Mehrez, Gil. 2005. "The Mexican informal sector and its implications", in IMF: Mexico: Selected issues. IMF Country Report No. 05/428. Washington, DC, pp. 6-21.

Ménard, Claude; Marais, Bertrand du. 2006. "Can we rank legal systems according to their economic efficiency?", in Peter Nobel and Marina Gets (eds): New frontiers of law and economics. Zurich, Schulthess, pp. 7-27.

Micco, Alejandro; Pagés, Carmen. 2004. Employment protection and gross job flows: A differences-in-differences approach. Research Department Working Paper No. 508. Washington, DC, Inter-American Development Bank.

Murray, Jill. 2001. Transnational labour regulation: The ILO and EC compared. The Hague, Kluwer Law International.

Oviedo, Ana María. 2006. Regulation, institutions and productivity growth. Dissertation submitted to the Faculty of the Graduate School of the University of Maryland, College Park, MD.

-.2004. The burden of regulation on young firms: A cross-country evaluation. College Park, MD, University of Maryland.

Palmer, Robert; Wedgwood, Ruth; Hayman, Rachel. 2007. Educating out of poverty? A Synthesis Report on Ghana, India, Kenya, Rwanda, Tanzania and South Africa. DFID Educational Paper No. 70. London, DFID/Centre of African Studies, University of Edinburgh.

Pierre, Gaëlle; Scarpetta, Stefano. 2007. How labor market policies can combine workers' protection with job creation: A partial review of some key issues and policy options. Social Protection Discussion Paper No. 0716. Washington, DC, World Bank.

-; - 2004. Employment regulations through the eyes of employers: Do they matter and how do firms respond to them? IZA Discussion paper No. 1424. Bonn, Institute for the Study of Labor (IZA).

Pissarides, Christopher A. 2001. "Employment protection", in Labour Economics, Vol. 8, No. 2, pp. 131-159.

Poschke, Markus. 2007. Employment protection, firm selection, and growth. IZA Discussion Paper No. 3164. Bonn, Institute for the Study of Labor (IZA).

Rodrik, Dani. 2005. Why we learn nothing from regressing economic growth on policies. Unpublished mimeo. Cambridge, MA, Harvard University.

Schiantarelli, Fabio. 2005. Product market regulation and macroeconomic performance: $A$ review of cross-country evidence. Policy Research Working Paper No. 3770. Washington, DC, World Bank.

Siems, Mathias. 2007. The end of comparative law. Working Paper No. 340. Cambridge, Centre for Business Research, University of Cambridge.

Trebilcock, Anne. 2006. "Using development approaches to address the challenge of the informal economy for labour law", in Guy Davidov and Brian Langille (eds): Boundaries and frontiers of labour law: Goals and means in the regulation of work. Oxford, Hart Publishing, pp. 63-86.

UNDP. 2004. Unleashing entrepreneurship: Making businesses work for the poor. Commission on the Private Sector and Development. New York, NY.

UNIDO/GTZ (United Nations Industrial Development Organization/Deutsche Gesellschaft für Technische Zusammenarbeit). 2008. Creating an enabling environment for private sector development in sub-Saharan Africa. Vienna.

USAID/VCCI (Vietnam Chamber of Commerce and Industry). 2007. Vietnam Provincial Competitiveness Index: Measuring economic governance for private sector development. Hanoi, VCCI.

Van Stel, André; Storey, David J.; Thurik, A. Roy. 2006. The effect of business regulations on nascent and young business entrepreneurship. ERIM Report No. ERS-2006-052-ORG. Rotterdam, Erasmus Research Institute of Management.

Villalba, Carolina. 2006. The World Bank insists on the liberalization of economies. Montevideo, IFIs Latin American Monitor.

World Bank. 2008. Doing Business 2008. Washington, DC.

-. 2007. Middle-East and North Africa Region 2007 Economic development and prospects: Job creation in an era of high growth. Washington, DC. 